Research paper

\title{
Zinc loaded whey protein nanoparticles mitigate the oxidative stress and modulate antioxidative gene expression in testicular tissues in rats
}

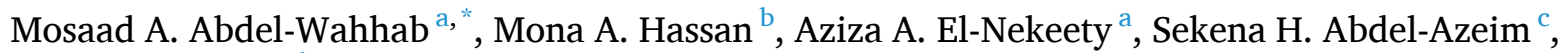 \\ Nabila S. Hassan ${ }^{\mathrm{d}}$, Irwandi Jaswir ${ }^{\mathrm{e}}$, Hamzah M. Salleh ${ }^{\mathrm{e}}$ \\ ${ }^{a}$ Food Toxicology and Contaminants Department, National Research Center, Dokki, Cairo, Egypt \\ ${ }^{\mathrm{b}}$ Food Evaluation and Food Science Department, National Organization for Drug Control and Research, Giza, Egypt \\ ${ }^{\mathrm{c}}$ Cell Biology Department, National Research Center, Dokki, Cairo, Egypt \\ ${ }^{\mathrm{d}}$ Pathology Department, National Research Center, Dokki, Cairo, Egypt \\ ${ }^{\mathrm{e}}$ International Institute for Halal Research \& Training (INHART), International Islamic University Malaysia, Gombak, Kuala Lumpur, Malaysia
}

\section{A R T I C L E I N F O}

\section{Keywords:}

Whey protein nanoparticles

Zinc citrate

Testicular injury

Oxidative stress

Drug delivery

Gene expression

\begin{abstract}
A B S T R A C T
This study aimed to utilize whey protein nanoparticles (WPNPs) and zinc (Zn) loaded WPNPs to protect against carbon tetrachloride $\left(\mathrm{CCl}_{4}\right)$-induced testicular damage in rats. $\mathrm{Zn}$ was loaded on WPNPs at three levels and $\mathrm{Zn}$ release was determined at different time intervals. Seventy male Wistar rats were divided into 7 groups and treated orally for 4 weeks as follows: the control group, $\mathrm{CCl}_{4}$-treated group $(0.5 \mathrm{ml} / 100 \mathrm{~g} \mathrm{b.w})$ twice a week, $\mathrm{CCl}_{4}$ plus WPNPs-treated group (300 mg/kg b.w), $\mathrm{CCl}_{4}$ plus $\mathrm{Zn}$ citrate-treated group ( $50 \mathrm{mg} / \mathrm{kg}$ b.w), and the groups treated with $\mathrm{CCl}_{4}$ plus the three $\mathrm{Zn}$-WPNPs formulations. Blood and testicular tissue samples were collected for different assays. Animals treated with $\mathrm{CCl}_{4}$ showed a significant decrease in body weight and relative weight of the testis, testosterone level, antioxidant enzymes activity and mRNA expression of Nrf2, HO-1 and NQO1 and increased Malondialdehyde (MDA), nitric oxide (NO) and mRNA expression of Keep1 and induced histological changes in the testis. WPNPs alone, Zn alone or Zn loaded WPNPs at the three levels protect against $\mathrm{CCl}_{4}$-induced testicular damage. These effects were more pronounced in the group received the fabrication with low $\mathrm{Zn}$ level. This study concluded that Zn-WPNPs could reduce the oxidative stress in the testicular tissue via different mechanisms mainly via the regulation of Nrf2-Keap1 antioxidative signaling pathway.
\end{abstract}

\section{Introduction}

Male sterility is an eminent clinical issue affecting more than $30 \%$ of men worldwide [1]. Several clinical disorders, including hypertension are almost occurred due to the over production of ROS and the decline of antioxidant capacity leading to the hypogonadism, androgens deficiency and the disorder of physiologically male sexual desire [2].

Carbon tetrachloride $\left(\mathrm{CCl}_{4}\right)$ is a widely used as an environmental toxicant model and well known to generate ROS, induce lipid peroxidation, damage to different organs, including the liver, kidneys, heart, brain and testis [3]. The mechanism by which $\mathrm{CCl}_{4}$ induce its toxicity mainly due to the bio-activation into trichloromethyl peroxy radical $\left({ }^{\circ} \mathrm{OOCCl}{ }_{3}\right)$ and trichloromethyl radical $\left({ }^{\circ} \mathrm{CCl}_{3}\right)$ by the cytochrome $\mathrm{P} 450$ [4].

Zinc $(\mathrm{Zn})$ is an essential element affecting the majority of vital processes in the body, such as cell proliferation, immune function, the protection against oxidative stress [5]. Its role as antioxidant is mainly due to the maintaining of sufficient metallothionein levels as the essential component for Copper/Zn SOD synthesis [6]. It has a vital role in DNA repair, cell division and differentiation and neuroprotective effects [7]. $\mathrm{Zn}$ is found in several proteins in the cells and responsible for a variety of biological activities including development, growth and reproduction [8]. A relatively high concentration of $\mathrm{Zn}$ was found in the male reproductive organs and its deficiency lead to gonadotoxicity and affect the male fertility [9] and impairs the development of testis and the steroidogenesis [10].

Zn supplementation cures various diseases such as infection growth failure, wounds and skin diseases as well as cancer [11,12]. WHO recommended the use of water-soluble $\mathrm{Zn}$ compounds like zinc gluconate, zinc sulfate or zinc acetate as tablets or syrups for the treatment of infant diarrhea [13]. Zn citrate is a promising sensory characterizes high $\mathrm{Zn}$ content, water soluble, odorless and comparatively low cost [14]. Zn sulfate, Zn gluconate and Zn citrate are absorbed equally in human;

\footnotetext{
* Corresponding author.

E-mail address: mosaad_abdelwahhab@yahoo.com (M.A. Abdel-Wahhab).
} 


\begin{tabular}{|c|c|c|c|}
\hline \multicolumn{2}{|c|}{ List of abbreviations } & $\begin{array}{l}\mathrm{NaCl} \\
\mathrm{NO}\end{array}$ & $\begin{array}{l}\text { Sodium Chloride } \\
\text { nitric oxide }\end{array}$ \\
\hline \multicolumn{2}{|c|}{ Abbreviations Full form } & NQO1 & $\mathrm{NAD}(\mathrm{P}) \mathrm{H}$ quinone dehydrogenase 1 \\
\hline${ }^{\bullet} \mathrm{CCl}_{3}$ & Trichloromethyl radical & Nrf2 & Nuclear factor erythroid 2-related factor 2 \\
\hline$\cdot \mathrm{OOCCl}_{3}$ & Trichloromethyl peroxy radical & qRT-PCR & Quantitative reverse transcriptase polymerase chain \\
\hline ARG & Arginine & & reaction \\
\hline $\mathrm{CCl}_{4}$ & Carbon tetrachloride & RIA & Radioimmunoassay \\
\hline DNA & Deoxyribonucleic Acid & ROS & Reactive oxygen species \\
\hline GLY & Glycine & SER & Serine \\
\hline GR & Glutathione reductase & SOD & Superoxide Dismutase \\
\hline GSH & Glutathione & STPP & Sodium tripolyphosphate \\
\hline GST & Glutathione -S- transferase & TEM & Transmission electron microscope \\
\hline HIS & Histidine & THR & threonine \\
\hline $\mathrm{HO}-1$ & Heme oxygenase- 1 & VAL & Valinine \\
\hline HPLC & High-Performance Liquid Chromatography & WP & Whey protein \\
\hline Keap1 & Kelch-like ECH-associated protein 1 & WPNPS & Whey protein nanoparticles \\
\hline MDA & Malondialdehyde & & Zinc \\
\hline METH & Methionine & Zn-WPNPs & S Zinc loaded whey protein nanoparticles \\
\hline mRNA & Messenger Ribonucleic Acid & & \\
\hline
\end{tabular}

however, the absorption of $\mathrm{ZnO}$ is weak [15]. Zn citrate showed similar absorbability to Zn acetate, sulfate, oxide and gluconate [16] although an in vitro study revealed that the gluconate and oxide forms showed higher dialyzability compared to Zn citrate [17].

Although zinc oxide is cheap and has no side effects regarding the sensory perception, it has a low bioavailability due to its insolubility at the gastric $\mathrm{pH}$ [18]. The application of nanotechnology in the food industry is a promising tool to improve the bioavailability of nutraceutical compounds [19], particularly the poor soluble arise from their subcellular sizes [20]. Whey protein (WP) is widely used by the manufacturers of food due to its functional-values, health-promoting, nutritional and its antioxidant bioactivity [21-23] and is utilized as a food additive and a drug delivery for oral administration $[19,24]$. Metal ions can bind to the functional groups such as sulphydryl, carboxyl, imidazole, amino acids and peptide groups [25]. This study aimed to loading zinc citrate on whey protein nanoparticles (WPNPs) to promote the absorption of zinc and enhance its protection role against testicular oxidative damage in $\mathrm{CCl}_{4}$-treated rats.

\section{Materials and methods}

\subsection{Materials, chemicals and kits}

Zinc citrate was purchased from El Nasr. Pharmaceutical Chemicals Co. (Cairo, Egypt). Whey protein isolate ( $92.6 \%$ proteins) was purchased from Davisco Foods International Inc. (MN, USA). Glutathione -Stransferase (GST), glutathione reductase (GR), glutathione (GSH) and nitric oxide (NO) kits were obtained from Eagle diagnostics (TX, USA). ${ }^{\mathrm{TM}} \mathrm{DNase}$ and the removal reagent kit was purchased from Promega, Co. (WI, USA). Sodium tripolyphosphate (STPP) and RevertAid ${ }^{\mathrm{TM}} \mathrm{H}$ Minus First Strand cDNA Synthesis Kits were purchased from Sigma Chemical Co. (St. Luis, Mo, USA). A radioimmunoassay (RIA) kit for testosterone was obtained from MyBioSource, Inc. (CA, USA) and malondialdehyde (MDA) kit purchased from Oxis Research ${ }^{\mathrm{TM}}$ Co. (PA, USA). TRIZOL reagent was purchased from InvitrogenTM (CA, USA). All chemicals used throughout the experiments were of the highest analytical grade available.

\subsection{Determination of amino acids and preparation of whey protein nanoparticles (WPNPs)}

The determination of amino acids in WPI was carried out by HPLC according to the method described by Hassan et al. [26]. WPNPs were prepared by the pH-cycling method previously described by Giroux et al. [27].

\subsection{Characterization of zinc loaded whey protein nanoparticles}

Zinc citrate loaded WPNPs was carried out according to the method described by Hassan et al. [26] at three concentrations: $7 \mathrm{mM} / \mathrm{g}$ (low dose; LD), $14 \mathrm{mM} / \mathrm{g}$ (medium dose; MD) and $28 \mathrm{mM} / \mathrm{g}$ (high dose; HD). The $\mathrm{z}$-average diameter and size distribution of WPNPs alone or Zn-WPNPs at the three levels were carried out using Nano ZS/ZEN3600 Zetasizer (Malvern Instruments Ltd., UK) with a He/Ne laser $(\lambda=633$ $\mathrm{nm}$ ), refractive index 1.35 and scattering angle $90^{\circ}$ scattering optics. The samples were prepared for TEM according to the method described by Moslehishad and Ezzatpanah [28]. The grid was air dried and examined by TEM using a JEOL JEM-1400 with an accelerating voltage of $100 \mathrm{kV}$ at a magnification of $200,000 \mathrm{x}$.

\subsection{In vitro zinc release}

In vitro release of zinc loaded whey protein nanoparticles was determined by using a dissolution apparatus (Sotax-CH-4123 AllSCWIL/ Basel Switzerland). The simulated gastric fluid was prepared according to Shao et al. [29]. In brief, $0.2 \mathrm{~g} \mathrm{NaCl}$ and $0.32 \mathrm{~g}$ pepsin were dissolved in $70 \mathrm{ml}$ Milli-Q water, and the $\mathrm{pH}$ was adjusted to 1.2 using $1 \mathrm{M} \mathrm{HCl}$. The solution was placed in a $100 \mathrm{ml}$ volumetric flask and diluted with water to a volume. The in vitro release of zinc-loaded WPNPs was evaluated according to Akbas et al. [30] with some modifications. Briefly, $10 \mathrm{mg}$ of freeze-dried samples were added to $5 \mathrm{ml}$ simulated gastric fluid. The mixture was incubated at $37{ }^{\circ} \mathrm{C}$ in $10 \mathrm{ml}$ glass tube in a shaking water bath. Two $\mathrm{ml}$ of the reactant were centrifuged at 1300 $\mathrm{rpm}$ and $25^{\circ} \mathrm{C}$ and the released of zinc in the supernatant fluid was taken at interval time ranged from 5 to $60 \mathrm{~min}$ then after $2 \mathrm{hs}$. Zinc was measured by atomic absorption flame spectrophotometer (Analytik Jena, Germany) computed with Aspect CS 2.1.1.0 software.

\subsection{Experimental animals}

Seventy sexually mature male Sprague-Dawley rats (3 months old, $120-130 \mathrm{~g}$ ) were purchased from the National Organization of Drug Control and Research (NODCR). The animals were maintained on a standard lab diet purchased from Meladco Feed Co., (Cairo, Egypt) in filter-top polycarbonate cages in a room free from any chemical contamination under standard condition of illumination with a $12 \mathrm{~h}$ 

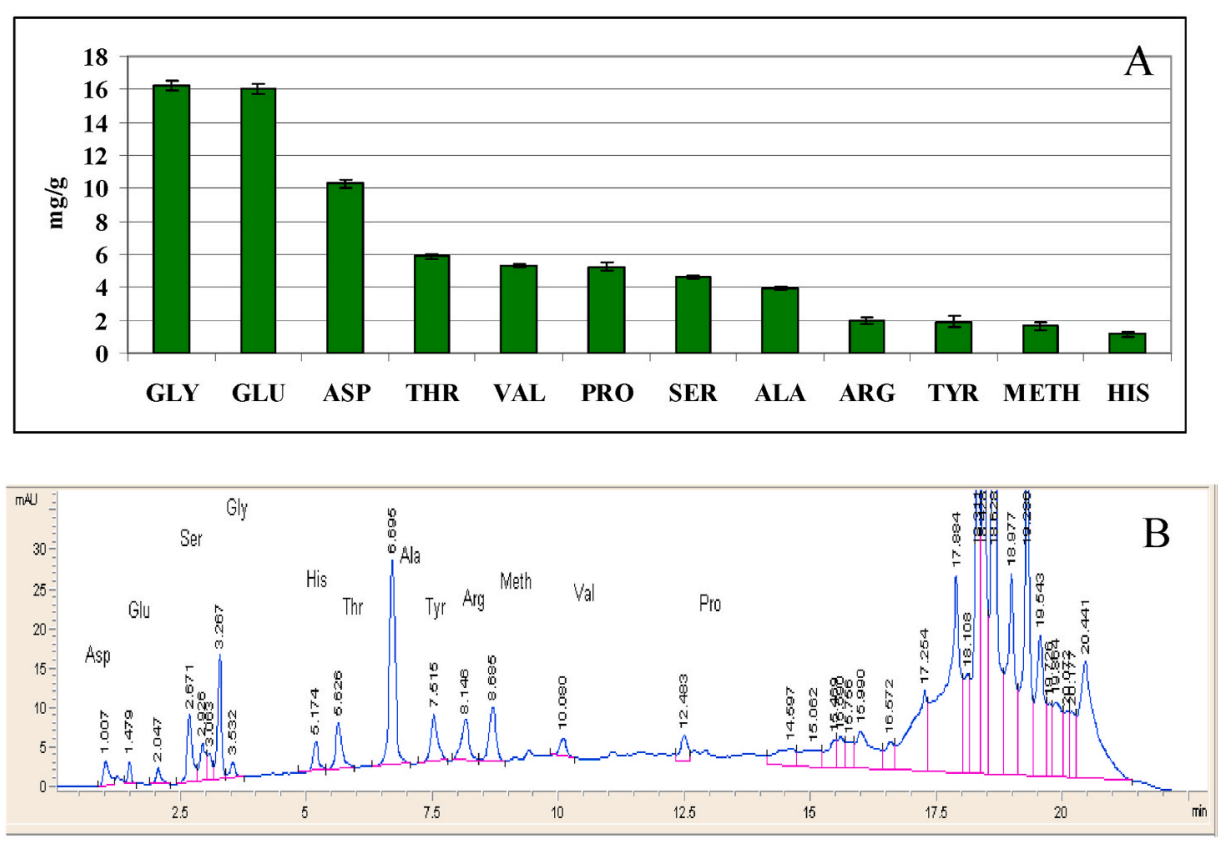

Fig. 1. Amino acids content (A) and HPLC chromatogram for amino acid in WPI (B).

dark/light cycle, $25 \pm 1^{\mathrm{O}} \mathrm{C}$ and humidity $(50 \pm 5 \%)$ at the Animal House Lab., NODCR, Giza, Egypt. All animals received humane care in compliance with the guidelines of the Animal Care and Use Committee of the National Research Centre and the National Institutes of Health (NIH publication 86-23 revised 1985).

\subsection{Experimental design}

After 1 week acclimatization period, the animals were divided into 7 groups (10 rats/group) and treated orally for four weeks included: the control group; the group treated with $\mathrm{CCl}_{4}(3.3 \%)$ in corn oil $(0.5 \mathrm{ml} /$ $100 \mathrm{~g} \mathrm{b.w}$ ) twice a week; the group treated with WPNP (300 mg/kg b.w.) plus $\mathrm{CCl}_{4}$; the group treated with $\mathrm{Zn}$ citrate $(50 \mathrm{mg} / \mathrm{kg} \mathrm{b} / . \mathrm{w})$ plus $\mathrm{CCl}_{4}$ and the groups treated with $50 \mathrm{mg} / \mathrm{kg}$ b.w of Zn1-WPNPs (7 mg/g), Zn2WPNPs ( $14 \mathrm{mg} / \mathrm{g}$ ) or $\mathrm{Zn} 3$-WPNPs $\left(28 \mathrm{mg} / \mathrm{g}\right.$ ) plus $\mathrm{CCl}_{4}$. Body weight was recorded in the first and last day. On day 28 , all animals were fasted for $12 \mathrm{~h}$ and then blood samples were collected from the retro-orbital venous plexus under diethyl ether anesthesia. The serum was separated from all samples using cooling centrifugation and stored at $-20{ }^{\mathrm{O}} \mathrm{C}$ until analysis for testosterone determination by radioimmunoassay (RIA) according to Chen et al. [31]. After the collections of blood samples all animals were sacrificed by cervical dislocation and samples of the two testes were collected, weighted. The testes index was calculated as relative weight as follows: left testes weight/body weight $\times 100$. Then three testis samples from each animal within different treatment groups were used for the determination of biochemical parameters, cytogenetic analysis and histological examination. One sample from each animal was dissected, weighed and homogenized in phosphate buffer (pH 7.4) to give $20 \% \mathrm{w} / \mathrm{v}$ homogenate and was used for the determination of MDA and NO then it was further diluted to give $2 \%$ and $0.5 \%$ dilution for the determination of testicular GR, GST and GSH activities [32]. Another sample from each animal was used for the determination of the molecular genetic analyses. The third testis sample from each animal was fixed in $10 \%$ neutral formalin and paraffin embedded. Sections $(5 \mu \mathrm{m}$ thickness) were stained with hematoxylin and eosin ( $\mathrm{Hx} \& \mathrm{E})$ for the histological examination [33].

\subsection{Molecular genetics analyses}

\subsubsection{RNA extraction and cDNA synthesis}

Total RNA (ribonucleic acid) was extracted from testis tissue samples using TRIzol ${ }^{\circledR}$ Reagent (Invitrogen ${ }^{\mathrm{TM}}$, Carlsbad, CA, USA) according to the manufacturer's instructions. The purity and concentration of RNA were measured using NanoDrop ${ }^{\mathrm{TM}} 1000$ Spectrophotometer (Thermo Fisher Scientific, USA). RNase-free DNase kit (Promega) was used to remove any DNA contamination from extracted RNA. DNase-treated RNA was reverse-transcribed into first-strand cDNA (complementary DNA) using a HiSenScript TM cDNA kit (Intronbio, Korea) in a $20 \mu \mathrm{l}$ reaction containing $1000 \mathrm{ng}$ total RNA according to the method described previously [26].

\subsubsection{Real-time PCR analysis}

The expression of phase II detoxifying/antioxidant enzymes like nuclear factor erythroid 2-related factor 2 (Nrf2), heme oxygenase 1 (HO-1), NAD(P)H quinone dehydrogenase 1(NQO1) and Kelch-like ECH-associated protein1 (Keap1) genes as well as Glyceraldehyde-3phosphate dehydrogenase (GAPDH) (as internal control), in all groups was determined by quantitative reverse transcriptase polymerase chain reaction (qRT-PCR). The primer sequences and their condition are shown in Table (1). RT-qPCR was carried out on Stratagene Mx3005P Real-Time PCR System (Agilent Technologies) in a $20 \mu \mathrm{L}$ reaction volume using, $1 \mu \mathrm{l}$ cDNA, $10 \mu \mathrm{M}$ of forward and reverse primers, $10 \mu \mathrm{L}$ TOPreal $^{\mathrm{TM}}$ qPCR 2X PreMIX (SYBR Green with low ROX) (Enzynomics) and DNAse-free water. All samples were amplified in a minimum of triplicates. Amplification was performed with a 15 min denaturation step at $95{ }^{\circ} \mathrm{C}$, followed by 40 cycles of $95^{\circ} \mathrm{C}$ for $15 \mathrm{Sec}, 58-60^{\circ} \mathrm{C}$ for 30 Sec and $72{ }^{\circ} \mathrm{C}$ for $30 \mathrm{Sec}$. To assess amplification specificity, melting curve analysis was performed. Relative gene expression levels normalized to GAPDH were calculated using the $2^{-\Delta \Delta \mathrm{Ct}}$ method [34] following the end of each reaction to confirm specific.

\subsection{Statistical analysis}

All data for biochemical parameters were statistically analyzed using the General Linear Models Procedure of the Statistical Analysis System. The significance of the differences among treatment groups was determined by Waller-Duncan k-ratio. All statements of significance were 

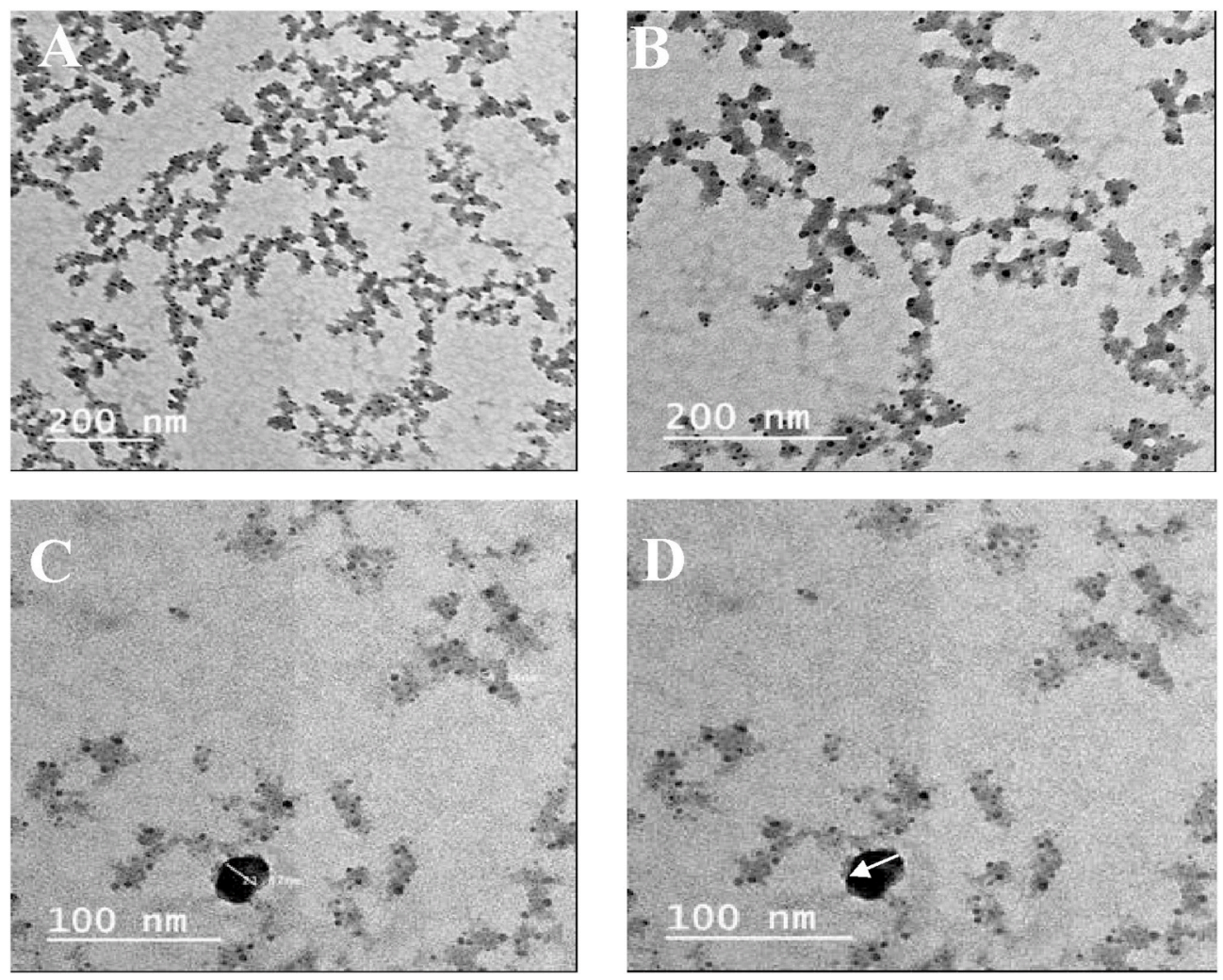

Fig. 2. TEM images for (A) WPNPs, (B) Zn1-WPNPs, (C) Zn2-WPNPs and (D) Zn3-WP-NPs.

based on probability of $\mathrm{P} \leq 0.05$.

\section{Results and discussion}

The HPLC analysis showed WPI contained 12 amino acids varied in their concentrations and glycine was the higher followed by glutamic acid then aspartic acid; however, histidine and methionine were the lowest amino acids (Fig. 1a and b). Despite no available data on the amino acids in WPNPs, a previous report showed that WPI contains threonine, aspratate and alanine in high concentrations and glutamate, proline and phenylalanine were found in low concentrations [35]. In a previous work, we reported that Zn-WPNPs at the low level contain the same amino acids of WPNPs [26]. However, several amino acids included METH, GLY, SER, HIS, ARG, VAL and THR were completely disappeared by increasing $\mathrm{Zn}$ ratio [26]. $\mathrm{Zn}$ level in the three formulas was $14.3 \%, 32.2 \%$ and $45.3 \%$, in Zn1-WPNPs, Zn2-WPNPs and Zn3-WPNPs, respectively. These levels were in the range recommended by UNICEF and WHO [36] for human consumption.

\subsection{Characterization of Zn-WPNPs}

TEM images of WPNPs alone or the three formulations of Zn-WPNPs revealed a semi spherical shape for Zn-WP-NPs. Zn appear as dark area in the images and the shape of Zn-WPNPs did not change were stable during the TEM analysis which indicated the strong binding between $\mathrm{Zn}$ and WPNPs. The average particle size of WPNPs and the three formulations of Zn-WPNPs were 98, 144, 197 and $230 \mathrm{~nm}$, respectively (Fig. 2a,b,c and d). The ratio of $\mathrm{Zn}$ in the three formulas was $14.3 \%$, $32.2 \%$ and $45.3 \%$, respectively. These results indicated that the incorporation of Zn to WPNPs did not change the shape of particles but it only affects the particles size and their zeta potential. Previously, Gülseren et al. [37] synthesized WPNPs incorporated with $\mathrm{Zn}$ in the average daily dose required for the healthy adults. However, the particles size reported herein was a bit higher compared to the particles size of Gülseren
Dissolution

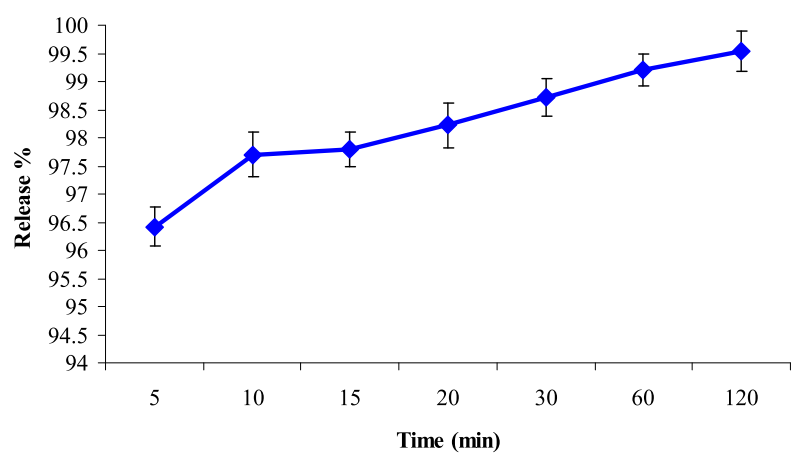

Fig. 3. Zinc release profile in gastric fluid from zinc loaded WPNPs (means $\pm \mathrm{SD})$.

et al. [38] who refer to the different method of preparation since metal ions able to bind to sulphydryl and peptides in the protein [25]. Additionally, WPNPs alone or Zn-WPNPs at the three doses showed a negative zeta potential value of $-95,-114,-85$ and -79 , respectively which is similar to those reported in our previous work [26].

\subsection{In vitro zinc release}

The data presented in Fig (3) showed the recoveries of zinc concentration at different time intervals $(5,10,15,20,25,30,60 \mathrm{~min}$ and 2 h). The obtained results from 6 replicates showed that the release rate was quite high. After $5 \mathrm{~min}$ the release was more than $96 \%$ of the analysis and it was $97.80,99.72,99.20 \%$ and $99.53 \%$ after $5,10,15,30$, $60 \mathrm{~min}$ and $2 \mathrm{~h}$, respectively. A high recovery of Zn was obtained after 5 min suggested that the formulas of Zn-WPNPs are more active for the stability and the duration of $\mathrm{Zn}$ release up to $2 \mathrm{~h}$. It can be extracted that 

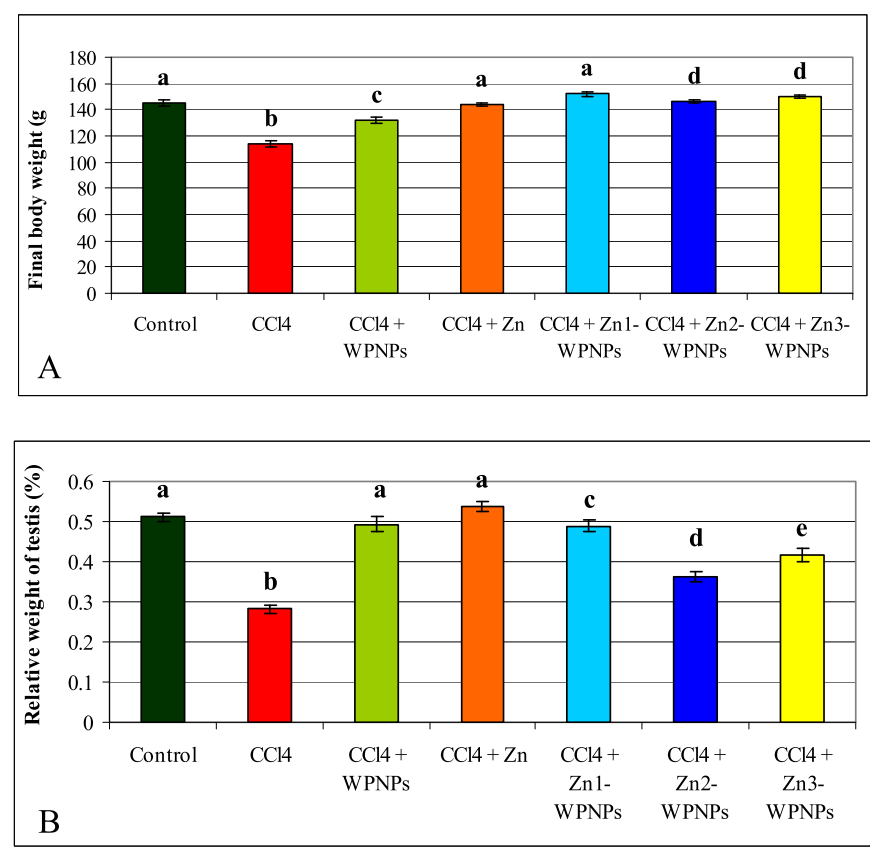

Fig. 4. Effect of WPNPs, Zn or Zn loaded WPNPs on final body weight (A) and relative weight of the testis (B).

Within each column, means superscript with different letters (a, b, c, ...) are significantly different $(\mathrm{P} \leq 0.05)$.

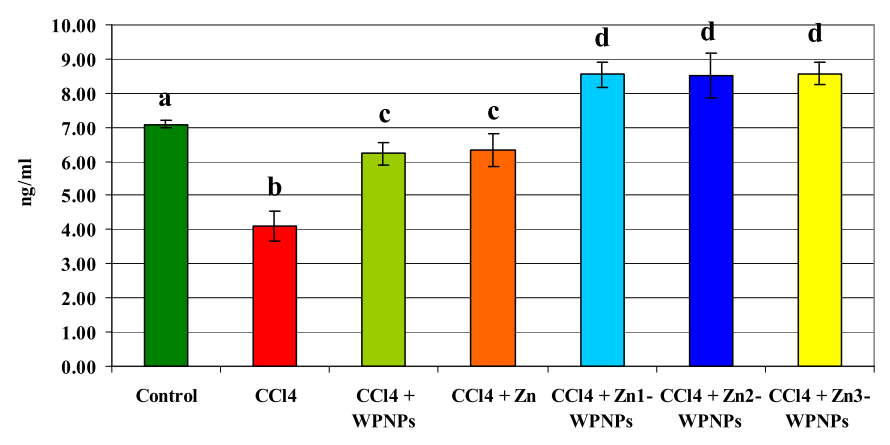

Fig. 5. Effect of WPNPs, $\mathrm{Zn}$ and $\mathrm{Zn}$ loaded WPNPs on testosterone level in rats treated with $\mathrm{CCl}_{4}$

Within each column, means superscript with different letters (a, b, c, ...) are significantly different $(\mathrm{P} \leq 0.05)$.
Table 2

Effect of WPNPs, Zn and Zn loaded WPNPs on oxidative stress markers and antioxidant enzyme activities in testes of rats treated with CCl4.

\begin{tabular}{|c|c|c|c|c|c|}
\hline $\begin{array}{l}\text { Parameter } \\
\text { Groups }\end{array}$ & $\begin{array}{l}\text { GR } \\
(\mu \mathrm{mol} / g)\end{array}$ & $\begin{array}{l}\text { GST } \\
(\mathrm{mu} / \mathrm{g})\end{array}$ & $\begin{array}{l}\text { GSH (mg/ } \\
\mathrm{g})\end{array}$ & $\begin{array}{l}\text { MDA } \\
(\mathrm{nmol} / \mathrm{g})\end{array}$ & $\begin{array}{l}\text { NO }(\mu \mathrm{nol} / \\
\mathrm{g})\end{array}$ \\
\hline Control & $\begin{array}{l}6.84 \pm \\
6.88^{\mathrm{a}}\end{array}$ & $\begin{array}{l}13.0 \pm \\
0.85^{\mathrm{a}}\end{array}$ & $\begin{array}{l}285.1 \pm \\
13.23^{\mathrm{a}}\end{array}$ & $\begin{array}{l}396.84 \pm \\
6.88^{\mathrm{a}}\end{array}$ & $\begin{array}{l}113.0 \pm \\
0.85^{\mathrm{a}}\end{array}$ \\
\hline $\mathrm{CCl}_{4}$ & $\begin{array}{l}3.16 \pm \\
9.27^{\mathrm{b}}\end{array}$ & $\begin{array}{l}5.33 \pm \\
0.33^{\mathrm{b}}\end{array}$ & $\begin{array}{l}152.4 \pm \\
1.17^{\mathrm{b}}\end{array}$ & $\begin{array}{l}650.16 \pm \\
9.27^{\mathrm{b}}\end{array}$ & $\begin{array}{l}225.33 \pm \\
0.33^{\mathrm{b}}\end{array}$ \\
\hline $\begin{array}{l}\mathrm{CCl}_{4}+ \\
\text { WPNPs }\end{array}$ & $\begin{array}{l}4.63 \pm \\
10.17^{\mathrm{c}}\end{array}$ & $\begin{array}{l}14.0 \pm \\
1.53^{\mathrm{a}}\end{array}$ & $\begin{array}{l}363.93 \pm \\
24.71^{c}\end{array}$ & $\begin{array}{l}428.63 \pm \\
10.17^{c}\end{array}$ & $\begin{array}{l}134.0 \pm \\
1.53^{\mathrm{c}}\end{array}$ \\
\hline $\mathrm{CCl}_{4}+\mathrm{Zn}$ & $\begin{array}{l}4.79 \pm \\
3.56^{\mathrm{c}}\end{array}$ & $\begin{array}{l}14.33 \pm \\
1.20^{\mathrm{a}}\end{array}$ & $\begin{array}{l}393.97 \pm \\
26.02^{\mathrm{d}}\end{array}$ & $\begin{array}{l}406.79 \pm \\
3.56^{\mathrm{d}}\end{array}$ & $\begin{array}{l}126.33 \pm \\
1.20^{\mathrm{d}}\end{array}$ \\
\hline $\begin{array}{c}\mathrm{CCl}_{4+} \mathrm{Zn1}- \\
\text { WPNPs }\end{array}$ & $\begin{array}{l}6.49 \pm \\
1.28^{\mathrm{a}}\end{array}$ & $\begin{array}{l}16.0 \pm \\
0.88^{\mathrm{c}}\end{array}$ & $\begin{array}{l}368.07 \pm \\
10.40^{\mathrm{c}}\end{array}$ & $\begin{array}{l}304.49 \pm \\
1.28^{\mathrm{e}}\end{array}$ & $\begin{array}{l}116.33 \pm \\
0.88^{\mathrm{a}}\end{array}$ \\
\hline $\begin{array}{c}\mathrm{CCl}_{4}+\mathrm{Zn} 2- \\
\text { WPNPs }\end{array}$ & $\begin{array}{l}5.49 \pm \\
4.08^{\mathrm{d}}\end{array}$ & $\begin{array}{l}14.73 \pm \\
0.33^{\mathrm{a}}\end{array}$ & $\begin{array}{l}353.73 \pm \\
8.50^{\mathrm{e}}\end{array}$ & $\begin{array}{l}304.49 \pm \\
4.08^{f}\end{array}$ & $\begin{array}{l}113.33 \pm \\
0.33^{\mathrm{a}}\end{array}$ \\
\hline $\begin{array}{c}\mathrm{CCl}_{4+} \mathrm{Zn} 3- \\
\text { WPNPs }\end{array}$ & $\begin{array}{l}5.27 \pm \\
2.50^{\mathrm{d}}\end{array}$ & $\begin{array}{l}15.73 \pm \\
0.58^{\mathrm{c}}\end{array}$ & $\begin{array}{l}325.20 \pm \\
12.14^{\mathrm{f}}\end{array}$ & $\begin{array}{l}311.27 \pm \\
2.50^{g}\end{array}$ & $\begin{array}{l}106.0 \pm \\
0.58^{\mathrm{e}}\end{array}$ \\
\hline
\end{tabular}

Data are presented as mean \pm SE.

Within each column, means superscript with different letters $(a, b, c, \ldots)$ are significantly different $(\mathrm{P} \leq 0.05)$.

the WPNPs is a good carrier and could act as a reservoir for zinc and confirmed that WPNPs can be used to encapsulate, protect and enhance the release profile of micronutrients. The results indicated that WPNPs have a high ability to bind $\mathrm{Zn}$ which may be due to the interaction between $\mathrm{Zn}$ ion with a positive charge and the negatively charged amino acids cysteine and histidine [38]. The obtained data are agreed with Gülseren et al. [39] who reported that the encapsulation capacity of WPNPs for zinc retained was high and remained stable for 30 days at $22{ }^{\circ} \mathrm{C}$.

\subsection{In vivo results}

The protective role of $\mathrm{Zn}$ alone WPNPs alone or $\mathrm{Zn}$ loaded WPNPs at three levels against $\mathrm{CCl}_{4}$.impairs testicular function was evaluated in rats. The selective doses of $\mathrm{CCl}_{4}$, $\mathrm{Zn}$, WPNPs or $\mathrm{Zn}$ loaded WPNPs were based on our previous work [26]. The current results also revealed that the final body weight (Fig. 4A) and the relative weight of the testis (Fig. 4B) were significantly decreased in the group treated with $\mathrm{CCl}_{4}$. WPNPs alone, $\mathrm{Zn}$ alone or $\mathrm{Zn}$ loaded WPNPs at the three levels ameliorated the toxicity of $\mathrm{CCl}_{4}$ and could protect against its adverse change in the weights. The improvement in final body weight was more pronounced in the group treated with $\mathrm{CCl}_{4}$ plus the high level of $\mathrm{Zn} \mathrm{(28}$ $\mathrm{mM} / \mathrm{g}$ ) loaded WPNPs. However, the improvement in the relative weight of the testis was clearer in the group treated with $\mathrm{CCl}_{4}$ plus $\mathrm{Zn}$.

The data presented in Fig. (5) revealed that $\mathrm{CCl}_{4}$ administration

Table 1

Gene bank accession numbers, primer sequences and conditions of the genes investigated by real-time RT-PCR.

\begin{tabular}{|c|c|c|c|}
\hline Gene & Sequence $\left(5^{\prime} \rightarrow 3^{\prime}\right)$ & Product size(bp) & 40 PCR cycles \\
\hline \multirow[t]{3}{*}{ Nrf2 (NM_031789) } & F: $5^{\prime}$ TTTGGAGGCAAGACATAG $3^{\prime}$ & 253 & $95^{\circ} \mathrm{C}$ for $15 \mathrm{~s}$ \\
\hline & R: $5^{\prime}$ TGGGCAACCTGGGAGTA $3^{\prime}$ & & $60{ }^{\circ} \mathrm{C}$ for $30 \mathrm{~s}$ \\
\hline & & & $72{ }^{\circ} \mathrm{C}$ for $30 \mathrm{~s}$ \\
\hline \multirow[t]{3}{*}{ HO-1 (NM_012580) } & F: $5^{\prime}$ TTCACCTTCCCGAGCAT $3^{\prime}$ & 110 & $95^{\circ} \mathrm{C}$ for $15 \mathrm{~s}$ \\
\hline & R: $5^{\prime}$ GCCTCTTCTGTCACCCTGT $3^{\prime}$ & & $60{ }^{\circ} \mathrm{C}$ for $30 \mathrm{~s}$ \\
\hline & & & $72{ }^{\circ} \mathrm{C}$ for $30 \mathrm{~s}$ \\
\hline \multirow[t]{3}{*}{ NQO1 (NM_017000) } & F: 5' CCATTCCAGCCGACAAC $3^{\prime}$ & 199 & $95^{\circ} \mathrm{C}$ for $15 \mathrm{~s}$ \\
\hline & R: $5^{\prime}$ AGCCGTGGCAGAACTATC $3^{\prime}$ & & $60{ }^{\circ} \mathrm{C}$ for $30 \mathrm{~s}$ \\
\hline & & & $72{ }^{\circ} \mathrm{C}$ for $30 \mathrm{~s}$ \\
\hline \multirow[t]{3}{*}{ Keap1 (NM_057152.1) } & F: 5' CTGCATCCACCACAGCAGCGT $3^{\prime}$ & 250 & $95^{\circ} \mathrm{C}$ for $30 \mathrm{~s}$ \\
\hline & R: 5 GTGCAGCACACAGACCCCGGC $3^{\prime}$ & & $58{ }^{\circ} \mathrm{C}$ for $30 \mathrm{~s}$ \\
\hline & & & $72{ }^{\circ} \mathrm{C}$ for $30 \mathrm{~s}$ \\
\hline \multirow[t]{3}{*}{ GAPDH (NM_001289726.1) } & F: 5' AACTTTGGCATTGTGGAAGG $3^{\prime}$ & 223 & $95^{\circ} \mathrm{C}$ for $15 \mathrm{~s}$ \\
\hline & R: 5' ACACATTGGGGGTAGGAACA $3^{\prime}$ & & $63{ }^{\circ} \mathrm{C}$ for $30 \mathrm{~s}$ \\
\hline & & & $72{ }^{\circ} \mathrm{C}$ for $30 \mathrm{~s}$ \\
\hline
\end{tabular}

Nrf2: NF-E2 related factor 2; HO-1: heme oxygenase-1; Keap1: Kelch-like ECH-associated protein1; NQO1: quinone oxidoreductase 1 and GAPDH: Glyceraldehyde-3phosphate dehydrogenase. 

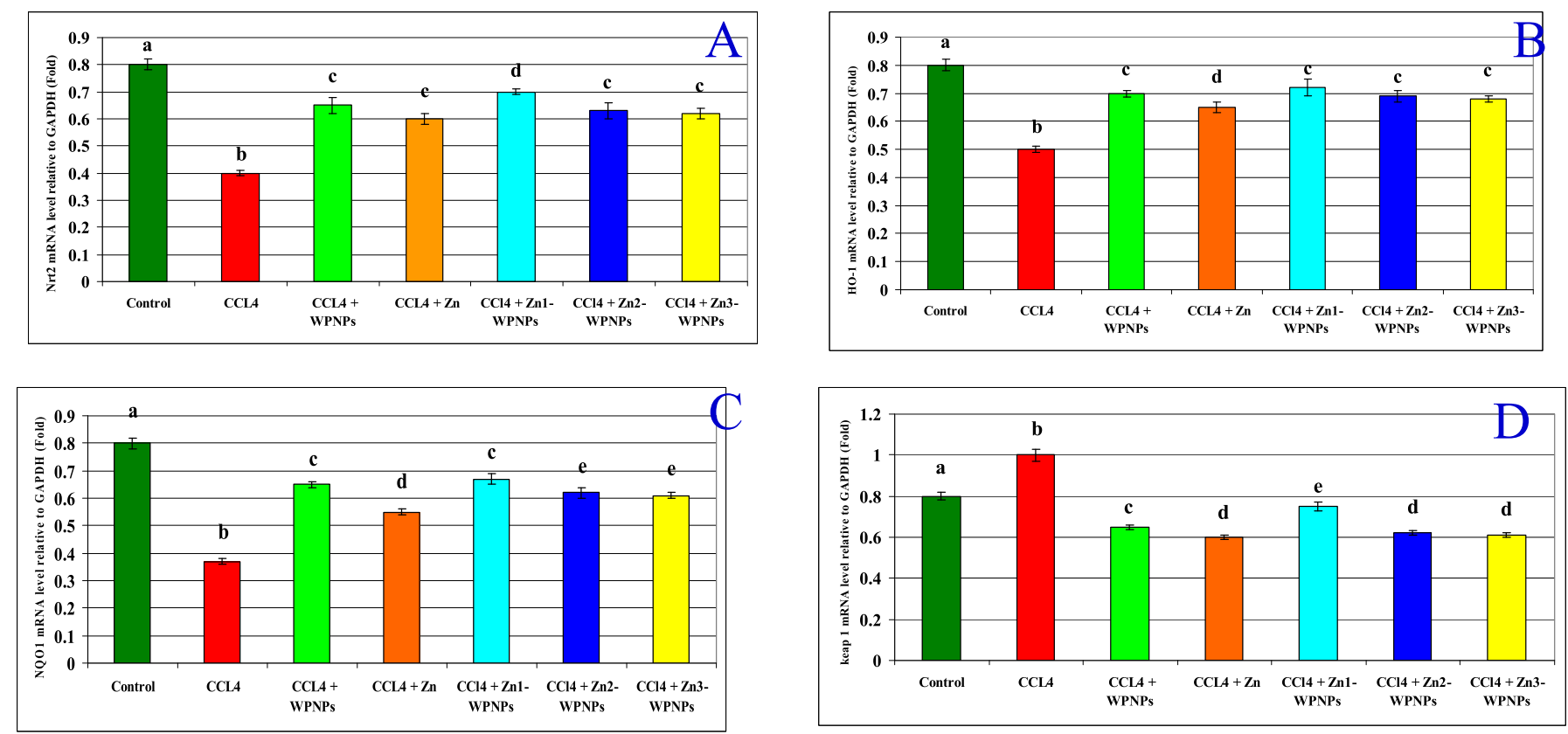

Fig. 6. Effect of WPNPs, $\mathrm{Zn}$ and $\mathrm{Zn}$ loaded WPNPs on the detoxifying/antioxidant enzymes mRNA gene expression in the testicular tissue of rats treated with $\mathrm{CCl}_{4}$ Within each column, means superscript with different letters $(a, b, c, \ldots)$ are significantly different $(P \leq 0.05)$.

induced a significant decrease in testosterone level compared to the control group. Co treatment with $\mathrm{CCl}_{4}$ plus WPNPs or $\mathrm{Zn}$ resulted in a significant improvement in testosterone level compared to $\mathrm{CCl}_{4}$-treated group. Moreover, no significant difference was observed in testosterone level between these two groups. On the other hand, the administration of $\mathrm{CCl}_{4}$ plus $\mathrm{Zn}$ loaded WPNPs at the three tested doses induced more improvement in testosterone level with no significant difference between these groups. Furthermore, testosterone level in these groups was higher than the control group. The data presented in Table (2) showed that $\mathrm{CCl}_{4}$ induced oxidative damage in the testis as indicated by the increase in testicular MDA and NO. WPNPs alone, $\mathrm{Zn}$ alone or $\mathrm{Zn}$ loaded WPNPs at the three tested levels succeeded to counteract the oxidative damage of $\mathrm{CCl}_{4}$ in testicular tissue. Moreover, $\mathrm{Zn}$ alone was more effective than WPNPs alone and Zn loaded WPNPs induced further protection; however, the high dose of $\mathrm{Zn}$ loaded WPNPs was more effective compared to the other formulas. These results confirmed the earlier findings which showed that $\mathrm{CCl}_{4}$ induce oxidative damage to several organs including the testis. $\mathrm{CCl}_{4}$ is well known as environmental toxicant and the basis of its toxicity lies in the free radical generation and the induction of oxidative stress via its biotransformation into trichloromethyl radical $\left(\mathrm{CCl}_{3}^{*}\right)$ by the hepatic Cyt $\mathrm{P}-450$ [40-42]. These radicals react with the polyunsaturated fatty acids leading to the formation of covalent adducts with lipids and microsomal proteins [43] resulting in the lipid peroxidation, damage of cell membranes and the injury of testis [44]. The increase level of $\mathrm{NO}$ also indicated the oxidative stress generated by $\mathrm{CCl}_{4}$. Although $N O$ radicals play a principal role in the inflammatory response; however, their toxicity appears only after the reaction with $02 \bullet-$ radicals and the formation of highly reactive peroxynitrite, which attack the biomolecules such as nucleic acids, proteins and lipids [45].

The alteration of antioxidant status in the testis of rats in different treatment groups is presented in Table (2) and showed that $\mathrm{CCl}_{4}$ administration decreased GR, GST and GSH. Animals treated with $\mathrm{CCl}_{4}$ plus WPNPs or $\mathrm{Zn}$ showed a significant improvement in the antioxidant parameters tested. Moreover, animals treated with $\mathrm{CCl}_{4}$ plus $\mathrm{Zn}$ loaded WPNPs showed pronounced improvement in the testicular antioxidant and the improvement was correlated with the $\mathrm{Zn}$ level since the high level of $\mathrm{Zn}$ loaded WPNPs showed the highest improvement of the antioxidant status. The decrease in antioxidant enzymes activity GR, GST and GSH in animals treated with $\mathrm{CCl}_{4}$ indicated the protein inactivation by ROS since oxidative damage leads to the depletion of protein function [46]. The oxidative damage in enzymes and the protein structure plays an important role in the pathophysiology of several diseases [47]. Actually, the decrease of antioxidant enzymes in the testicular tissue in $\mathrm{CCl}_{4}$-treated animals was reported previously [48] and indicated the decrease in the bioavailability of GSH due to the enhancement of lipid peroxidation and/or the inactivation of the antioxidant enzymes during oxidative stress and the accumulation of superoxide anion $\mathrm{O}_{2}$ [49]. $\mathrm{CCl}_{4}$ induced a significant decrease in serum testosterone level, which may be directly through the degeneration of Leydig cells due to the excessive oxidative stress [48] or indirectly through the stimulation of $\mathrm{P} 450$, which catalyses the production of estrogen from androgen $[50,51]$ as was reported by several authors [52, 53].

The effect of $\mathrm{Zn}$ loaded WPNPs against oxidative stress in rats treated with $\mathrm{CCl}_{4}$ was further investigated via the evaluation of the detoxifying/ antioxidant enzymes Nrf2 (Fig. 6A), HO-1 (Fig. 6B), NQO1 (Fig. 6C) and Keap1 (Fig. 6D) gene expression levels that involved in testis remodeling. The results revealed that the administration of $\mathrm{CCl}_{4}$ induced a down regulation of Nrf2, HO-1 and NQO1 accompanied with the up-regulation of Keap1 mRNA expression compared to the control group. Co-treatment with $\mathrm{CCl}_{4}$ plus WPNPs, $\mathrm{Zn}$ or $\mathrm{Zn}$ loaded WPNPs at the three tested levels induced a significant improvement in the mRNA expression of the tested genes. It is worthy to mention that animals treated with Zn1-WPNPs showed the best improvement in the expression of Nrf2, NQO1 and Keap-1 mRNA. However, no significant difference was observed in Ho-1 mRNA expression between the groups treated with $\mathrm{Zn}$, WPNPs alone or the medium or high level of Zn loaded WPNPs although these treatments significantly attenuated the increase in Keap-1mRNA levels compared to $\mathrm{CCl}_{4}$-treated group. Nrf2 is confined in cytosol via the interacting with the specific repressor Keap1 [54]. During the oxidative stress, the Nrf2 dissociates from Keap1 and moves to the nucleus to regulate the expression of different antioxidant-related genes such as HO-1. Hence, Nrf2 is a critical transcription factor for the protection against the excessive oxidative stress [55] and the target genes [56]. It is well documented that the Nrf2-ARE signaling is a key pathway for the cellular antioxidant and the antioxidant enzyme and the enzymes responsible for phase II detoxification are regulated via this signaling pathway to eliminate the harmful ROS [57]. Activation of Nrf2-ARE 

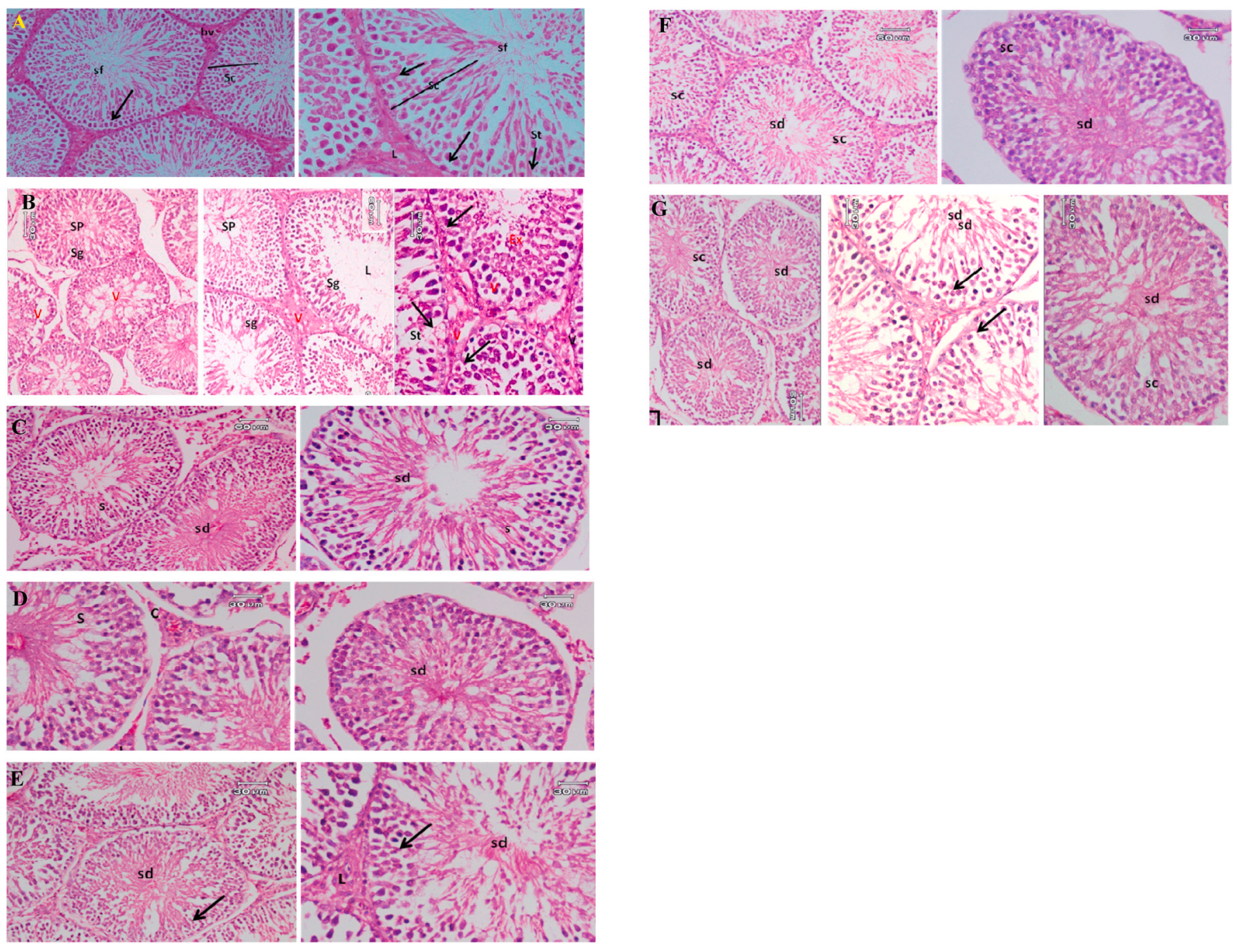

Fig. 7. Low and high power of photomicrographs of transverse section (T.S) of testis of:

A: control group showing normal seminiferous tubules with rounded and regular outline. The interstitial spaces showed Ledig cells (L) and normal capillaries (b.v). Notice the whorly appearance of sperm flagella (sf), normal spermatogenic cells (sc) formed of layers of different stages of spermatogenesis, spermatogonia cells (st), spermatocytes, spermatid (St), sertoli cell (St; small arrow) appears pyramidial and resting on the basement membrane. Notice Ledig cells in the interstitial spaces (L), B: Testis of rats treated with $\mathrm{CCl}_{4}$ showing disturbance and disappearance of seminiferous tubules spermatogenic series ( $\mathrm{Sg}$ ) with vacuolar degeneration and pyknotic nuclei, some tubules have enlarged lumen without sperm (L) vacuolation and exfoliation cells (EX). Enlarged interstitium with vacuolaion and aggregation of leydig's cells,

C: Testis of rats treated with $\mathrm{CCl}_{4}$ plus WPNPs showing intact epithelium of seminiferous tubules and nearly complete spermatogenic germ cell series, spermatogonia cells, spermatocytes and spermatid (sd) with whorly appearance of sperm flagella. Few tubules show separation of spermatogenic cells from tubule basement membrane and disorganization,

D: Testis of rats treated with $\mathrm{CCl}_{4}$ plus $\mathrm{Zn}$ showing restoration of the normal structure in most of seminiferous tubules and interstitium congested blood vessels. Notice, the lumen fill with sperms flagella,

E: Testis of rats treated with $\mathrm{CCl}_{4}$ plus Zn1-WPNPs showing rearrangement of seminiferous tubules spermatogenic series, sertoli cells (arrow) and lumen filled with considerable amount of sperm (Sd). The interstitium with normal leydig's cells also seen,

F: Testis of rats treated with $\mathrm{CCl}_{4}$ plus Zn2-WPNPs showing intact seminiferous tubules with normal spermatozoa in the lumen (Sd), complete spermatogenic germ cell series (sc) and interstitial Ledig's cells,

G: Testis of rats treated with $\mathrm{CCl}_{4}$ plus Zn3-WPNPs showing considerable improvement in epithelium of seminiferous tubules, complete spermatogenic germ cell series, spermatogonia cells, spermatocytes, spermatid (sd) and the Sertoli cells with whorly appearance of sperm flagella. The interstitial spaces show acidophilic exudates and congested blood vessels.

signaling pathway induces the transcription of several protective genes, including HO-1 and GSH to overcome the oxidative damage [58]. On the other hand, Keep1 undergoes oxidation as a response to oxidative signals and this leads to Nrf2 stabilization [59]. Activation of Nrf2 through the binding with ARE promote the downstream gene expression mainly HO-1 which is considered the strongest antioxidant to improve cell survival [60].

The histological examination of testis of control group (Fig. 7A) showed normal seminiferous tubules with rounded and regular outline,
Leydig's cells and normal capillaries were found in the interstitial spaces. The same sections showed the appearance of sperm flagella and normal spermatogenic cells formed of layers in different stages of spermatogenesis, spermatogonia, spermatocytes and spermatids. Sertoli cells were also appeared pyramidal and resting on the basement membrane. The testis sections of rats treated with $\mathrm{CCl}_{4}$ (Fig. 7B) showed disturbance and disappearance of seminiferous tubules spermatogenic series with vacuolar degeneration and pyknotic nuclei, some tubules have enlarged lumen without sperm, vacuolation and exfoliation cells 
along with enlarged interstitium with vacuolaion and aggregation of Leydig's cells. The examination of testis sections of rats treated with $\mathrm{CCl}_{4}$ plus WPNPs (Fig. 7C) showed intact epithelium of the seminiferous tubules and nearly complete spermatogenic germ cell series, spermatogonia cells, spermatocytes and spermatids with whorly appearance of sperm flagella. Few tubules showed separation of spermatogenic cells from tubule basement membrane and disorganization. Animals treated with $\mathrm{CCl}_{4}$ plus $\mathrm{Zn}$ alone (Fig. 7D) showed restoration of the normal structure in most of seminiferous tubules and interstitium congested blood vessels. The testis sections of rats treated with $\mathrm{CCl}_{4}$ plus $\mathrm{Zn1-}$ WPNPs (Fig. 7E) showed rearrangement of seminiferous tubules spermatogenic series and Sertoli cells. The lumen filled appeared with considerable amount of sperm and normal Leydig's cells were seen in the interstitium. Moreover, the testis of animals treated with $\mathrm{CCl}_{4}$ plus Zn2-WPNPs (Fig. 7F) showed intact seminiferous tubules with normal spermatozoa in the lumen and complete spermatogenic germ cell series and interstitial Ledig's cells. The animals treated with Zn3-WPNPs (Fig. 7G) showed considerable improvement in epithelium of seminiferous tubules and complete spermatogenic germ cell series, spermatogonia cells, spermatocytes, spermatid and the Sertoli cells with whorly appearance of sperm flagella. The interstitial spaces also showed acidophilic exudates and congested blood vessels. Similar observations were reported by El-Faras et al. [52] who found a marked degeneration of the spermatogenic layers and interlobular hemorrhage. Al-Olayan et al. [48] reported a prominent inflammation, complete swallowing of seminiferous tubules and degenerated germ cells in the testis or rats treated with $\mathrm{CCl}_{4}$. Moreover, Rahmouni et al. [53] reported that $\mathrm{CCl}_{4}$ induced disorganization and atrophy in seminiferous tubules.

$\mathrm{Zn}$ is the essential trace element affected the majority of different vital processes. It affects the cell proliferation, the immune system and protect against free radicals generation and oxidative stress via its role in the antioxidant activation [5]. In male reproductive organs, $\mathrm{Zn}$ is found in relatively high concentrations [61] and responsible for the regulation of several physiological activities including apoptosis and cell proliferation [62]. $\mathrm{Zn}$ is playing a critical role in the conservation of germ cells and spermatogenesis development [56]. Its deficiency leads to apoptosis to germ cells due to high oxidative stress [62]; however, excess $\mathrm{Zn}$ also has adverse long-term effects on the epigenome [63]. In the current study, WPNPs, Zn or Zn loaded WPNPs at the three tested levels showed a protective role against $\mathrm{CCl}_{4}$-induced testicular oxidative stress. Animals treated with $\mathrm{CCl}_{4}$ plus WPNPs, Zn or Zn-WPNPs showed a significant improvement in body weight, relative weight of testis, testosterone level along with a significant decrease in testicular MDA, NO and a significant increase in GR, GST and GSH. Moreover, a significant improvement was observed in the histological picture and the concerned genes expression mainly Nrf2, HO-1, NQO1 and Keap1 which are responsible for detoxifying/antioxidant enzymes. WP is widely used in the food industry due to its health-promoting and functional-values activities [22]. The protective role of WP is mainly due to its higher content of amino acids and sulfhydryl compounds which enhance the production of GSH, the main tool for the protection against oxidants [64]. Moreover, the synthesis of WPNPs enhanced the antioxidant capacity since these particles can encounter various cell types since the size of $100 \mathrm{~nm}$ make these particles able to enter the cell [65]. However, the protective effect of $\mathrm{Zn}$ is attributed to its role to protect the biological structures against free radicals through the maintenance of an adequate metallothioneins level and it is an essential for SOD synthesis [66]. Zn also protects thiol groups and prevents their interaction with other chemical and the formation of disulfide which may lead to the loss of enzyme activity [67]. Moreover, it prevents peroxidation of lipid in microsome membranes and mitochondria and stabilizes the structure of cell membrane and prevents the osmotic fragility of the erythrocyte membranes [68].

Taken together, both WPNPs and $\mathrm{Zn}$ are well known as protective agents against $\mathrm{CCl}_{4}$-induced testicular damage. Interestingly, the improvement in testicular tissue in the groups treated with $\mathrm{CCl}_{4}$ plus $\mathrm{Zn}$ loaded WPNPs indicated a synergistic effect of both agents. Nevertheless, the group treated with Zn1-WPNPs was better than those treated with Zn2-WPNPs and Zn3-WPNPs. This can be explained by the amount of amino acids in these formulas since some amino acids were absent by increasing the Zn level. For instance, METH, THR, HIS, VAL and ARG were absent in the formula Zn2-WPNPs and METH, GLY, SER, HIS, ARG, VAL and THR were absent in the formula Zn3-WPNPs. The disappearance of these amino acids in the two formulas reflects their antioxidant potential and their protective role against testicular oxidative damage [69].

\section{Conclusion}

WPNPs with average particle size of $98 \mathrm{~nm}$ can be synthesized. Zn loaded WPNPs at levels of $14.3 \%, 32.2 \%$ and $45.3 \%$ increased the particles size to 144, 197 and $230 \mathrm{~nm}$, respectively. $\mathrm{Zn}$ release from the fabrication was $96 \%$ after $5 \mathrm{~min}$ and reached $99.53 \%$ after $2 \mathrm{~h} \mathrm{CCl}_{4}$ impairs testicular tissues, decreased testosterone level, the antioxidant enzymes activity and down-regulates mRNA expression of mRNA of Nrf2, HO-1 and NQO1, increased MDA, NO and up-regulated mRNA expression of Keep1. $\mathrm{CCl}_{4}$ also induced histological changes in the testis. WPNPs alone, $\mathrm{Zn}$ alone or $\mathrm{Zn}$ loaded WPNPs at the three levels showed protective effects against $\mathrm{CCl}_{4}$-induced testicular damage. These effects were more pronounced in the group received the fabrication with low $\mathrm{Zn}$ level. It could be concluded that Zn-WPNPs could reduce the oxidative stress in the testicular tissue via different mechanisms mainly via the upregulation of Nrf2-Keap1 antioxidative signaling pathway.

\section{CRediT author statement}

This work was carried out in collaboration between all authors. Authors MA Hassan, AA El-Nekeety, SH Abdel-Azeim and NS Hassan carried out the experimental work and shared in writing the first draft of the manuscript. Author I Jaswir and HM Salleh managed the literature searches and performed the statistical analysis and shared in writing the first draft of the manuscript. Authors MA Abdel-Wahhab wrote the protocol, managed the project, managed the analyses of the study and wrote the final draft of the manuscript. All authors read and approved the final manuscript.

\section{Declaration of competing interest}

The authors declare that they have no known competing financial interests or personal relationships that could have appeared to influence the work reported in this paper.

\section{Acknowledgments}

This work was supported by the National Organization for Drug Control and Research, Giza, Egypt; the National Research Centre, Dokki, Cairo, Egypt project \# 12050305 and Konsortium Institut Halal Malaysia (KIHIM) grant \# MOHE18-002-0002.

\section{References}

[1] A.M. Isidori, C. Pozz, A.S. Isidori, Medical treatment to improve sperm quality, Reprod. Biomed. Online 12 (2006) 704-714.

[2] O.A. Ojo, A.B. Ojo, B. Ajiboye, A. Fadaka, O.B. Imiere, O. Adeyonu, et al., Protective influence of Ficus asperifolia Miq leaf extract on carbon tetrachloride ( $\mathrm{CCl}_{4}$ )-induced testicular toxicity in rats, J. Appl. Pharmacol. 6 (2016) 37-41, 06.

[3] S. Meftah, R. Yazdanparast, M. Molaei, Ameliorative action of Mn-Salen derivatives on $\mathrm{CCl}_{4}$-induced destructive effects and lipofuscin-like pigment formation in rats' liver and brain: post-treatment of young rats with EUKs, CellBio 3 (2014) 96-110.

[4] S.O. Anadozie, J.A. Akinyemi, S. Agunbiade, B.O. Ajiboye, O.B. Adewale, Bryophyllum pinnatum inhibits arginase II activity and prevents oxidative damage occasioned by carbon tetrachloride $\left(\mathrm{CCl}_{4}\right)$ in rats, Biomed. Pharmacother. 101 (2018) 8-13.

[5] A.S. Prasad, Zinc is an antioxidant and anti-inflammatory agent: its role in human health, Front Nutr 1 (2014) 14. 
[6] D. Bogani, M.A. Morgan, A.C. Nelson, I. Costello, J.F. McGouran, B.M. Kessler, et al., The PR/SET domain zinc finger protein Prdm4 regulates gene expression in embryonic stem cells but plays a nonessential role in the developing mouse embryo, Mol. Cell Biol. 3 (2013) 3936-3950.

[7] A. Soussi, M. Gargouri, A. El Feki, Effects of co-exposure to lead and zinc on redox status, kidney variables, and histopathology in adult albino rats, Toxicol. Ind. Health 4 (7) (2018) 469-480.

[8] M. Messaoudi, L. Banni, K. Saïd, A. Saïd, A. Kerkeni, Evaluation of involvement of testicular metallothionein gene expression in the protective effect of zinc against cadmium-induced testicular pathophysiology in rat, Reprod. Toxicol. 29 (2010) $339-345$.

[9] M. Chemek, S.B. Mimouna, S. Boughammoura, G. Delbès, I. Messaoudi, Protective role of zinc against the toxicity induced by exposure to cadmium during gestation and lactation on testis development, Reprod. Toxicol. 63 (2016) 151-160.

[10] S.A. Hamdi, O.I. Nassif, M.S. Ardawi, Effect of marginal or severe dietary zinc deficiency on testicular development and functions of the rat, Arch. Androl. 38 (1997) 243-253.

[11] J.M. Cho, J.Y. Kim, H.R. Yang, Effects of oral zinc supplementation on zinc status and catch-up growth during the first 2 years of life in children with non-organic failure to thrive born preterm and at term, Pediatr Neonatol 60 (2) (2019) 201-209.

[12] X. Yu, S. Kogan, Y. Chen, A.T. Tsang, T. Withers, H. Lin, et al., Zinc Metallochaperones Reactivate mutant p53 using an ON/OFF switch mechanism: a new paradigm in cancer therapeutics, Clin. Canc. Res. 24 (18) (2018) 4505-4517.

[13] WHO, UNICEF, Johns Hopkins Bloomberg School of Public Health, USAID, Implementing the New Recommendations on the Clinical Management of Diarrhoea: Guidelines for Policy Makers and Programme Managers, World Health Organization, Geneva (Switzerland), 2006.

[14] R. Wegmüller, F. Tay, C. Zeder, M. Brnic, R.F. Hurrell, Zinc absorption by young adults from supplemental zinc citrate is comparable with that from zinc gluconate and higher than from zinc oxide, J. Nutr. 144 (2) (2014) 132-136.

[15] M. Siepmann, S. Spank, A. Kluge, A. Schappach, W. Kirch, The pharmacokinetics of zinc from zinc gluconate: a comparison with zinc oxide in healthy men, Int. J. Clin. Pharm. Ther. 43 (2005) 562-565.

[16] J. Bertinato, L. Sherrard, L.J. Plouffe, EDTA disodium zinc has superior bioavailability compared to common inorganic or chelated zinc compounds in rats fed a high phytic acid diet, J. Trace Elem. Med. Biol. 26 (2012) 227-233.

[17] A. Guillem, A. Alegria, R. Barbera, R. Farre, M.J. Lagarda, G. Clemente, In vitro dialyzability of zinc from different salts used in the supplementation of infant formulas, Biol. Trace Elem. Res. 75 (2000) 11-19.

[18] R.S. Gibson, E.L. Ferguson, Nutrition intervention strategies to combat zinc deficiency in developing countries, Nutr. Res. Rev. 11 (1998) 115-131.

[19] S. Ko, S. Gunasekaran, Preparation of sub-100-nm beta-lactoglobulin (BLG) nanoparticles, J. Microencapsul. 23 (8) (2006) 887-898.

[20] L. Shi, J. Zhou, S. Gunasekaran, Low temperature fabrication of ZnO-whey protein isolate nanocomposite, Mater. Lett. 62 (2008) 4383-4385.

[21] A.B. MacAdam, Z.B. Shafi, C. Marriott, G.P. Martin, S.L. James, Anti-mucus polyclonal antibody production, purification and linkage to the surface of albumin microspheres, Int. J. Pharm. 195 (1-2) (2000) 147-158.

[22] O.L. Ramos, R.N. Pereira, A. Martins, et al., Design of whey protein nanostructures for incorporation and release of nutraceutical compounds in food, Crit. Rev. Food Sci. Nutr. 57 (2017) 1377-1393.

[23] Q.X. Zhang, Y.F. Ling, Z. Sun, et al., Protective effect of whey protein hydrolysates against hydrogen peroxide-induced oxidative stress on PC12 cells, Biotechnol. Lett. 34 (2012) 2001-2006.

[24] A.R. Corrochano, V. Buckin, P.M. Kelly, L. Giblin, Invited review: whey proteins as antioxidants and promoters of cellular antioxidant pathways, J. Dairy Sci. 101 (6) (2018) 4747-4761.

[25] E. Ocak, Distribution of contaminated heavy metals in milk, Asian J. Chem. 22 (2010) 6335-6340.

[26] M.A. Hassan, A.A. El-Nekeety, S.H. Abdel-Aziem, N.S. Hassan, M.A. AbdelWahhab, Zinc citrate incorporation with whey protein nanoparticles alleviate the oxidative stress complication and modulate gene expression in the liver of rats, Food Chem. Toxicol. 125 (2019) 439-445.

[27] H.J. Giroux, J. Houde, M. Britten, Preparation of nanoparticles from denatured whey protein by pH-cycling treatment, Food Hydrocolloids 24 (2010) 341-346.

[28] M. Moslehishad, H. Ezzatpanah, Transmission electron microscopy study of casein micelle in raw milk with different somatic cell count levels, Int. J. Food Prop. 13 (3) (2010) 546-552.

[29] S. Shao, X. Shen, M. Guo, Zinc-loaded whey protein nanoparticles prepared by enzymatic cross-linking and desolvation, Int. J. Food Sci. Technol. 53 (2018) 2205-2211.

[30] E. Akbas, M. Kilercioglu, O.N. Onder, A. Koker, B. Soyler, M.H. Oztop, Wheatgrass juice to wheat grass powder: encapsulation, physical and chemical characterization, J Funct Foods 28 (2017) 19-27.

[31] A. Chen, J.J. Bookstein, D.R. Meldrum, Diagnosis of a testosterone-secreting adrenal adenoma by selective venous catheterization, Fertil. Steril. 55 (1991) 1202-1203.

[32] C.C. Lin, Y.F. Hsu, T.C. Lin, F.L. Hsu, H.Y. Hsu, Antioxidant and hepatoprotective activity of punicalagin and punicalin on carbon tetrachloride-induced liver damage in rats, J. Pharm. Pharmacol. 50 (1998) 789-794.

[33] R.A.V. Drury, E.A. Wallington, Carltons Histological Techniques, fifth ed., Oxford University Press, New York, Pronto, 1980, p. 206 SY.

[34] K.J. Livak, T.D. Schmittgen, Analysis of relative gene expression data using realtime quantitative PCR and the 2(-Delta Delta C (T)) method, Methods 25 (4) (2001) 402-408.
[35] D.S. Kalman, Amino acid composition of an organic brown rice protein concentrate and isolate compared to soy and whey concentrates and isolates, Foods 3 (2014) 394-402.

[36] WHO/UNICEF, Department of Child and Adolescent Health and Development, World Health Organization. 'Reduced Osmolarity Oral Rehydration Salts (ORS) Formulation- Report from a Meeting of Experts Jointly Organized by UNICEF and WHO' (WHO/FCH/CAH/01.22), 2001. New York, 18 July.

[37] İ. Gülseren, Y. Fang, M. Corredig, Zinc incorporation capacity of whey protein nanoparticles prepared with desolvation with ethanol, Food Chem. 135 (2) (2012) 770-774.

[38] N. Tang, L.H. Skibsted, Zinc bioavailability from whey. Enthalpy-entropy compensation in protein binding, Food Res. Int. 89 (2016) 749-755.

[39] I. Gülseren, Y. Fang, M. Corredig, Whey protein nanoparticles prepared with desolvation with ethanol: characterization, thermal stability and interfacial behavior, Food Hydrocolloids 29 (2012) 258-264.

[40] S. Vatakuti, W.G. Schoonen, M.L. Elferink, G.M. Groothuis, P. Olinga, Acute toxicity of $\mathrm{CCl}_{4}$ but not of paracetamol induces a transcriptomic signature of fibrosis in precision-cut liver slices, Toxicol. Vitro 29 (5) (2015) 1012-1020.

[41] J.E. Packer, T.F. Slater, R.L. Willson, Reaction of the carbon tetrachloride related peroxy free radical $\left(\mathrm{CCL}_{3} \mathrm{O}_{2}^{-}\right)$with amino acids pulse radiolysis evidence, Life Sci. 23 (1978) 2617-2620.

[42] S. Dutta, A.K. Chakraborty, P. Dey, P. Ka, P. Guha, S. Sen, et al., Amelioration of $\mathrm{CCl}_{4}$ induced liver injury in swiss albino mice by antioxidant rich leaf extract of Croton bonplandianus Baill, PLoS One 13 (4) (2018), e0196411.

[43] S. Rabiei, M. Rezaei, Z. Abasian, M. Khezri, M. Nikoo, M. Rafieian-Kopaei, et al., The protective effect of Liza klunzingeri protein hydrolysate on carbon tetrachloride-induced oxidative stress and toxicity in male rats, Iran. J. Basic Med. Sci. 22 (10) (2019) 1203-1210.

[44] S. Szymonik-Lesiuk, G. Czechowska, M. Stryjecka-Zimmer, M. Slomka, A. Madro, K. Celinski, et al., Catalase, superoxide dismutase, and glutathione peroxidase activities in various rat tissues after carbon tetrachloride intoxication, J. Hepatobiliary Pancreat. Surg. 10 (4) (2003) 309-315.

[45] A.S. Gad, Y.A. Khadrawy, A.A. El-Nekeety, S.R. Mohamed, N.S. Hassan, M. A. Abdel-Wahhab, Antioxidant activity and hepatoprotective effects of whey protein and spirulina in rats, Nutrition 27 (5) (2011) 582-589.

[46] N. Amzar, M. Iqbal, The hepatoprotective effect of Clidemia hirta against carbon tetrachloride $\left(\mathrm{CCl}_{4}\right)$-induced oxidative stress and hepatic damage in mice, J. Environ. Pathol. Toxicol. Oncol. 36 (4) (2017), 293-30.

[47] A.E. Abdel Moneim, The neuroprotective effects of purslane (Portulaca oleracea) on rotenone-induced biochemical changes and apoptosis in brain of rat, CNS Neurol. Disord. - Drug Targets 12 (6) (2013) 830-841.

[48] E.M. Al-Olayan, M.F. El-Khadragy, D.M. Metwally, A.E. Abdel Moneim, Protective effects of pomegranate (Punica granatum) juice on testes against carbon tetrachloride intoxication in rats, BMC Compl. Alternative Med. 14 (164) (2014), https://doi.org/10.1186/1472-6882-14-164.

[49] M. Sönmez, G. Türk, S. Çeribaşı, M. Çiftçi, A. Yüce, M. Güvenç, et al., Quercetin attenuates carbon tetrachloride-induced testicular damage in rats, Andrologia 46 (8) (2014) 848-858.

[50] H.E. Chemes, V.Y. Rawe, The making of abnormal spermatozoa: cellular and molecular mechanisms underlying pathological spermiogenesis, Cell Tissue Res. 341 (2010) 349-357.

[51] A.M. Santos, M.R. Ferraz, C.V. Teixeira, F.J. Sampaio, R.C. da Fonte, Effects of undernutrition on serum and testicular testosterone levels and sexual function in adult rats, Horm. Metab. Res. 36 (1) (2004) 27-33.

[52] A.A. El-Faras, I.A. Sadek, Y.E. Ali, M. Khalil, E.B. Mussa, Protective effects of vitamin $\mathrm{E}$ on $\mathrm{CCl}_{4}$-induced testicular toxicity in male rats, Phys. Int. 103 (2) (2016) $157-168$.

[53] F. Rahmouni, S. Daoud, T. Rebai, Teucrium polium attenuates carbon tetrachloride-induced toxicity in the male reproductive system of rats, Andrologia 51 (2) (2019), e13182, https://doi.org/10.1111/and.13182.

[54] K. Taguchi, H. Motohashi, M. Yamamoto, Molecular mechanisms of the Keap1-Nrf2 pathway in stress response and cancer evolution, Gene Cell. 16 (2) (2011) 123-140.

[55] Q.M. Chen, A.J. Maltagliati, Nrf2 at the heart of oxidative stress and cardiac protection, Physiol. Genom. 50 (2) (2018) 77-97.

[56] Y. Zhao, Y. Tan, J. Dai, B. Li, L. Guo, J. Cui, Exacerbation of diabetes-induced testicular apoptosis by zinc deficiency is most likely associated with oxidative stress, p38 MAPK activation, and p53 activation in mice, Toxicol. Lett. 200 (2011) $100-106$.

[57] Y. Hou, Y. Wang, Q. He, L. Li, H. Xie, Y. Zhao, et al., Nrf2 inhibits NLRP3 inflammasome activation through regulating Trx1/TXNIP complex in cerebral ischemia reperfusion injury, Behav. Brain Res. 336 (2018) 32-39.

[58] L. Li, H. Dong, E. Song, X. Xu, L. Liu, Y. Song, Nrf2/ARE pathway activation, HO-1 and NQO1 induction by polychlorinated biphenyl quinone is associated with reactive oxygen species and PI3K/AKT signaling, Chem. Biol. Interact. 209 (2014) 56-67.

[59] T. Suzuki, H. Motohashi, M. Yamamoto, Toward clinical application of the Keap1Nrf2 pathway, Trends Pharmacol. Sci. 34 (2013) 340-346.

[60] M. Wang, X.J. Zhang, R. Feng, Y. Jiang, D.Y. Zhang, C. He, et al., Hepatoprotective properties of Penthorum chinense Pursh against carbon tetrachloride-induced acute liver injury in mice, Chin. Med. J. 12 (2017) 32, https://doi.org/10.1186/ s13020-017-0153-x.

[61] C.T. Chasapis, A.C. Loutsidou, C.A. Spiliopoulou, M.E. Stefanidou, Zinc and human health: an update, Arch. Toxicol. 86 (2012) 521-534.

[62] N. Ahangar, M. Naderi, A. Noroozi, M. Ghasemi, E. Zamani, F. Shaki, Zinc deficiency and oxidative stress involved in valproic acid induced hepatotoxicity: 
protection by Zinc and Selenium supplementation, Biol. Trace Elem. Res. 179 (2017) 102-109.

[63] W. Maret, H.H. Sandstead, Zinc requirements and the risks and benefits of zinc supplementation, J. Trace Elem. Med. Biol. 20 (1) (2006) 3-18.

[64] A.M. Hassan, S.H. Abdel-Aziem, M.A. Abdel-Wahhab, Modulation of DNA damage and alteration of gene expression during aflatoxicosis via dietary supplementation of Spirulina (Arthrospira) and whey protein concentrate, Ecotoxicol. Environ. Saf. 79 (2012) 294-300.

[65] S.R. Saptarshi, A. Duschl, A.L. Lopata, Interaction of nanoparticles with proteins: relation to bio-reactivity of the nanoparticle, J. Nanobiotechnol. 11 (2013) 26, https://doi.org/10.1186/1477-3155-11-26.
[66] W.E. Stehbens, Oxidative stress, toxic hepatitis, and antioxidants with particular emphasis on zinc, Exp. Mol. Pathol. 75 (3) (2003) 265-276.

[67] P.N. Gibbs, M.G. Gore, P.M. Jordan, Investigation of the effect of metal ions on the reactivity of thiol groups in human 5-aminolaevulinate dehydratase, Biochem. J. 225 (3) (1985) 573-575.

[68] H. Tapiero, K.D. Tew, Trace elements in human physiology and pathology: zinc and metallothioneins, Biomed. Pharmacother. 57 (9) (2003) 399-411.

[69] E. Park, H.D. Paik, S.M. Lee, Combined effects of whey protein hydrolysates and probiotics on oxidative stress induced by an iron-overloaded diet in rats, Int. J. Food Sci. Nutr. 69 (3) (2018) 298-307. 